\title{
SIMPTOMI I DIJAGNOSTIČKA KLASIFIKACIJA INTERNET ZAVISNOSTI U SRBIJI
}

\section{Darko Hinić ${ }^{1}$}

Medicinski fakultet, Univerzitet u Kragujevcu, Srbija

Predmet ove studije je utvrdivanje tipične kliničke slike poremećaja Internet upotrebe u Srbiji, kao i provera valjanosti skale Internet zavisnosti $u$ predviđanju ovog poremećaja. Sekundarni cilj bi bila evaluacija predloga da se ovaj poremećaj svrsta u dijagnostičku kategoriju bihevioralnih adikcija.

Studija je zamišljena kao komparativna analiza ponašanja Internet korisnika sa/bez simptoma prekomerne i nefunkcionalne upotrebe Interneta. U studiji je učestvovalo ukupno 100 ispitanika, 50 u kliničkoj i 50 u kontrolnoj grupi. Kliničku grupu su činili Internet korisnici koji su potražili stručnu terapeutsku pomoć zbog simptoma prekomerne upotrebe Interneta $i$ ispunili dijagnostičke kriterijume poremećaja Internet ponašanja. Tipični simptomi evidentirani su adaptiranom skalom psiho-fizičkih simptoma.

Kliničku sliku poremećaja Internet upotrebe čine četiri donekle odvojene dimenzije simptoma: opsesivna-kompulsivnost, depresivnost, hostilnost, anksioznost i emotivna osetljivost, pri čemu utvrdene dimenzije simptoma Internet zavisnosti odgovaraju teorijski pretpostavljenim simptomima/poremećajima koji prouzrokuju nastanak samog poremećaja. Važan nalaz studije je da se Skala zavisnosti pokazala visoko diskriminativna (odds ratio -1,557) u predvidanju poremećaja upotrebe Interneta. Skala zavisnosti se takode nalazi u visokoj korelaciji $\left(r_{b}=0,708, p<, 001\right)$ sa pomenutim poremećajem što daje empirijske osnove da pomenuti oblik ponašanja možemo klasifikovati u bihevioralne adikcije.

Ključne reči: bolesti zavisnosti, dijagnostički kriterijumi, Internet zavisnost

\footnotetext{
${ }^{1}$ e-mail: dahinfla@ptt.rs
} 


\section{Uvod}

Od 1995. godine, kada je Ivan Goldberg prvi put pomenuo pojam Internet zavisnost (Internet Addiction Disorder) javljaju se novi predlozi za njegov naziv i klasifikaciju (Yellowlees \& Marks, 2007). Iako poremećaj ponašanja na Internetu ispunjava gotovo sve dijagnostičke kriterijume adiktivnog ponašanja, klasifikacija ovog poremećaja i dalje izaziva brojne polemike u psihijatrijskim i psihološkim krugovima. Osnovni razlog leži u tome što u ovom slučaju ne postoji unošenje štetne supstance $u$ organizam, što je jedan od osnovnih kriterijuma pri dijagnozi nekog oblika zavisnosti. Zagovornici teze da bi poremećaj ponašanja na Internetu ipak trebalo klasifikovati u oblike adikcija rešenje vide u njegovom svrstavanju u grupu zavisnosti od određenih aktivnosti i radnji ili bihevioralnih adikcija (Thomas et al., 1999; Holden, 2001). Pošto se poremećaji kao što su kockanje i kompulsivna kupovina još uvek zvanično svrstavaju u poremećaje kontrole nagona i impulsa, termin kompulsivna upotreba Interneta je takođe često pominjano rešenje koje naglašava kompulsivnu prirodu ovog poremećaja. Daleko manje korišćeni su i termini patološka upotreba Interneta (Davis, 2001), internetomanija i slični nazivi.

Bez obzira na dileme oko klasifikacije, istraživači i kliničari su se okrenuli deskripciji tipične kliničke slike, kao i utvrđivanju lista dijagnostičkih kriterijuma ovog poremećaja. Najstariju listu predstavljaju adaptiranih osam kriterijuma koji su ranije korišćeni za dijagnozu patološkog kockanja (Young, 1998). Ova lista je takođe korišćena i u ovom istraživanju:

- tolerancija - izražena potreba za povećanom upotrebom Interneta radi postizanja prvobitnog zadovoljstva;

- apstinencijalna kriza - simptomi (anksioznost, depresivno raspoloženje, razdražljivost i sl.) se javljaju pri pokušaju smanjenja upotrebe ili lišavanja;

- umanjena ili izgubljena sposobnost kontrole upotrebe Interneta;

- osoba učestalo ostaje na Internetu duže nego što je planirala;

- preokupacija Internetom (objektom zavisnosti) - osoba neprestano misli na prethodnu ili anticipira narednu onlajn aktivnost;

- javljaju se problemi u socijalnim odnosima (porodica, prijatelji) i obavljanju svakodnevnih poslovnih/školskih obaveza usled povećane upotrebe Interneta;

- osoba skriva svoje ponašanje i prikriva u kom stepenu koristi Internet; 
- Internetu se pristupa kao sredstvu rešavanja ili bežanja od aktuelnih problema (nesposobnosti, tuge, krivice, anksioznosti...).

Prema analogiji sa ispitivanjem patološkog kockanja, kriterijum za dijagnozu predstavlja ispunjenje prvih pet kriterijuma (ili više), tokom perioda od godinu dana, a stroži, pored tih pet kriterijuma i jedan od preostala tri (Beard \& Wolf, 2001). Do danas, broj ovih lista se povećao, a takođe je konstruisano i nekoliko skala Internet zavisnosti, kao što su IAS (Young, 1998), CIAS (Cheng et al., 2003) i druge. Međutim, rezultati tih istraživanja su često više nego zbunjujući i neretko kontradiktorni. Najbolji primer za to je pitanje zastupljenosti kliničke populacije u ukupnoj populaciji Internet korisnika, što bi trebalo da je jedan od osnovnih podataka o ovom poremećaju. Dobijeni rezultati se kreću, iako na sličnim populacijama u teritorijalnom i vremenskom smislu, od 3\% (Mitchell, 2000; Whang, Lee \& Chang, 2003) do 15\% (Bai, Lin \& Chen, 2001), pa čak i do 25-30\% u nekim studijama (Chou, 2001). Najveći problem leži u metodologiji istraživanja koja su uglavnom eksplorativnog karaktera, ali i u načinu dolaženja do ispitanika, neusaglašenosti kriterijuma, i korišćenim instrumentima koji se razlikuju od istraživanja do istraživanja. Takođe, granica između kriterijuma i simptoma poremećaja je često nejasna jer se odlike poremećaja (simptomi definisani dijagnostičkim kriterijumima) u realnosti mešaju i poistovećuju sa sekundarnim simptomima izazvanim samim poremećajem. Navešćemo najočigledniji primer. Kriterijum za dijagnozu je povećano korišćenje Interneta. Međutim, najčešće se klijent ne žali na tu činjenicu, već na posledice koje takvo ponašanje stvara, na primer problemi sa očima, bolovi u leđima, poremećaj apetita i spavanja, nerazumevanje okoline i sl.

Činjenica da je evidentan porast korišćenja Interneta u Srbiji, kao i broj osoba koje se žale na simptome prekomerne upotrebe istog, nameće potrebu za pravovremenim ispitivanjem ove pojave i preventivnim dejstvom radi njenog amortizovanja u našoj sredini. U tom cilju sprovedena je do sada najšira empirijska studija ponašanja osoba sa poremećajem upotrebe Interneta u Srbiji. U ovom konkretnom članku, fokusiraćemo pažnju samo na jedan aspekt tog istraživanja koji se javlja kao logičan nastavak empirijske analize korisničkih profila Internet zavisnika već publikovane u časopisu Psihologija (Hinić, 2008). Predmet ovog dela te studije je deskripcija kliničke slike kod osoba koje se žale na simptome prekomerne upotrebe Interneta u Srbiji, kao i davanje predloga za eventualnu modifikaciju kriterijuma dijagnostikovanja, odnosno standardizaciju neke od postojećih skala Internet adikcije za našu sredinu. 


\section{Metod}

Prikupljanje podataka za celokupnu studiju sprovedeno je tokom perioda od pet meseci. Klinička grupa, grupa ispitanika koji su zatražili stručnu psihološku/psihijatrijsku pomoć, formirana je uz pomoć institucija/ordinacija u kojima su „Internet zavisnici“ zatražili savetovanje. Na osnovu karakteristika kliničke grupe određene su dodatne kvote za selekciju kontrolne grupe, prema parametrima značajnim za populaciju Internet korisnika, a radi ujednačavanja kontrolnih varijabli i adekvatne komparativne analize. Nakon početne selekcije i date saglasnosti svi ispitanici iz kliničke grupe su testirani navedenim instrumentima uz primenu polustrukturiranog intervjua, dok je kontrolna grupa anonimno ispitana elektronskim putem i nakon selekcije primenom ulaznih kriterijuma i postavljenim stratifikacijskim kvotama, slučajnim izborom oformljena sa unapred zadatim brojem ispitanika.

\section{Uzorak i postupak}

Ispitivanjem je konačno obuhvaćeno 100 Internet korisnika, uzrasta od 16 godina i starijih. Uzorak je po svojim karakteristikama prigodan i stratifikovan. Kliničku grupu je činilo 50 ispitanika koji su potražili stručnu pomoć zbog simptoma prekomerne i nefunkcionalne upotrebe Interneta, i koji su ispunili kriterijume zavisnosti od Interneta predložene od strane Američkog udruženja psihologa. Da bi se izbegao efekat tretmana kod članova kliničke grupe, kao i problem prisećanja, u konačan uzorak uključeni su samo oni ispitanici koji su stručnu pomoć potražili u poslednjih šest meseci. Iz studije su takođe isključeni ispitanici koji su u poslednjih par nedelja patili od neke ozbiljnije fizičke bolesti jer je to moglo uticati na rezultate na nekim od merenih varijabli u celokupnoj studiji (npr. depresivnost). Kontrolnu grupu je činilo 50 Internet korisnika koji se ne žale na simptome prekomerne upotrebe i ispunjavaju ulazne kriterijume - a) da koriste Internet više od godinu dana (jer je to dovoljan period da osoba stekne znanje, veštine i iskustvo potrebno za adekvatno snalaženje u sajber-prostoru); b) minimum pet sati nedeljno, jer na ovaj način izuzimamo osobe koje Internet koriste povremeno i u ograničenom obimu njegovih mogućnosti; c) i da ne ispunjavaju navedene dijagnostičke kriterijume Internet zavisnosti.

Problem slučajnosti uzorka je amortizovan primenom stratifikovanog uzorka, kojim je kontrolna grupa uravnotežena prema parametrima značajnim za populaciju korisnika Interneta, a to su pol, uzrast, obrazovanje, mesto stanovanja, ekonomski status i rasna pripadnost (Nie \& Erbring, 2000; Golčevski i Milanović, 2003; Cole, 2003; Madden \& Rainie, 2003). Stratifikacija kontrol- 
nog uzorka izvršena je u vrednostima koje se kreću u opsegu evidentiranih vrednosti kliničke grupe. $\mathrm{Na}$ osnovu tih vrednosti definisano je da se odnos polova može kretati u proporciji 40 prema 60 procenata u oba smera. Po uzrasnim kategorijama korišćena je raspodela sa najmanje 15\% učešća najstarije kategorije dok su ostale dve (adolescenti i osobe do 30 godina) mogle biti u odnosu 40 prema 45 procenata. Na osnovu zvanične regionalizacije Srbije, ispitani su korisnici Interneta iz pet regiona Srbije (Beograd, Vojvodina, Zapadna, Istočna i Južna Srbija), sa minimum 10\% udela poslednja tri regiona u populaciji ispitanih, dok su kvote za Beograd odnosno Vojvodinu mogle iznositi 30 prema 40 procenata. Za obrazovni status nije određena kvota jer on prati uzrasne kategorije, kao ni za ekonomski status koji je uopšteno viši u populaciji korisnika Interneta.

\section{Instrumenti}

U svrhu prikupljanja podataka za svaki od gore navedenih predmeta istraživanja, konstruisani su i primenjeni sledeći instrumenti:

- upitnik o upotrebi Interneta, kojim su prikupljene informacije o sociodemografskim karakteristikama uzorka, kao i karakteristikama i intenzitetu upotrebe Interneta;

- klinički intervju kojim su ispitani kriterijumi adiktivnog ponašanja predloženi od strane Američke asocijacije psihologa, adaptirani za prekomernu upotrebu Interneta (Hinić et al., 2008);

- skala simptoma, koristeći SCL-90-R listu simptoma (Derogatis, 1977; Derogatis, 1981) adaptiranu za psihodijagnostičke potrebe naše sredine (Timotijević \& Paunović, 2003) identifikovani su najintenzivniji simptomi kod osoba sa poremećajem u ponašanju na Internetu, tako što se od ispitanika tražilo da na skali od 0 (nema simptoma) do 4 (jako prisustvo simptoma) ocene intenzitet ponuđenih simptoma u trenutku kada su se obratili za stručnu pomoć. Odluka da se ova lista koristi doneta je u saradnji sa terapeutima kojima su se članovi kliničke grupe obratili za pomoć, jer se smatra da ona najbolje obuhvata sve simptome koji su zabeleženi prilikom njihovog prijema, izuzev socijalnih posledica, pri čemu je lista već uspešno primenjivana u stranim istraživanjima slične tematike (Yen et al., 2008);

- skala Internet adikcije, kojom se kvantitativno meri prisustvo potencijalnih simptoma Internet adikcije - skala je specijalno konstruisana za ovo istraživanje po ugledu na postojeće inostrane skale Internet zavisnosti, kao što su Internet Addiction Scale (Young, 1998), Chinese Internet Addiction Scale (Cheng et al., 2003), ali i domaće (Bugarski, 2003). Skala se sastoji od 20 ajtema na koje ispitanik odgovara pomoću petostepene Likertove skale. 
Skorovanje je preuzeto iz pomenutih skala (Young, 1998), a rezultati se u njima klasifikuju na sledeći način: 20-49 poena: normalna upotreba Interneta, korisnik pokazuje potpunu kontrolu ponašanja; 50-79 poena: blaži oblik poremećaja upotrebe Interneta, korisnik doživljava povremene probleme usled prekomerne upotrebe Interneta; 80-100 poena: težak oblik poremećaja upotrebe Interneta, koji prouzrokuje značajne i konstantne probleme u životu korisnika. Pošto se ovde radi o adaptiranoj skali, čiji razredi za stepene zavisnosti nisu još provereni na domaćoj populaciji, $u$ ovom konkretnom istraživanju nismo klasifikovali ispitanike po predloženim nivoima zavisnosti, ali ćemo ih hipotetički uzeti u obzir pri tumačenju rezultata naših ispitanika.

Upitnik o upotrebi Interneta, takođe je konstruisan po valjanoj proceduri na osnovu pregleda postojećih instrumenata iz literature, kao i onih koji su korišćeni u više domaćih istraživanja (Milanović, Bakić i Golčevski, 2002; Golčevski i Milanović, 2003; Golčevski, Milanović, Petrović i Sitarski, 2004; Hinić, 2007). Nakon primene nekoliko verzija na probnim uzorcima ispitanika, izabrana je konačna verzija.

\section{Rezultati}

Radi potpunije slike o populaciji koja je predmet ove studije, iznećemo ukratko podatke o sociodemografskim karakteristikama (Tabela 1.) i načinu upotrebe Interneta kliničke grupe (Tabela 2.), koji su detaljnije prikazani u već publikovanom radu (Hinić, 2008), gde su i statistički upoređeni sa podacima o zastupljenosti odgovarajućih kategorija u opštoj populaciji Internet korisnika.

Tabela 1. Demografske karakteristike kliničke grupe

\begin{tabular}{|c|c|c|c|c|c|c|c|c|}
\hline pol & $\%$ & uzrast & $\%$ & obrazovanje & $\%$ ek. status & $\%$ & region & $\%$ \\
\hline muški & 46.0 & $<19$ god & 40.0 & učenici & 40.0 nizak & 1.0 & Beograd & 32.0 \\
\hline \multirow[t]{4}{*}{ ženski } & 54.0 & 20-30 god. & 46.0 & studenti & 34.0 niži srednji & 7.0 & Vojvodina & 38.0 \\
\hline & & $>30$ god. & 14.0 & srednja škola & 14.0 viši srednji & 77.0 & Zap.Srbija & 10.0 \\
\hline & & & & više/visoko & visok & 15.0 & Ist.Srbija & 12.0 \\
\hline & & & & & & & Juž.Srbija & 8.0 \\
\hline
\end{tabular}


Po pitanju karakteristika upotrebe, predstavnici kliničke grupe, koju uglavnom čine iskusniji korisnici, najčešće pristupaju Internetu od kuće. Najveći deo njih aktivno provodi više od 20 sati nedeljno onlajn (pojedinci i po 40), skoro svi pristupaju Internetu više puta u toku dana (većina njih ima stalnu onlajn konekciju i učestalo se vraća Internetu u toku dana), a na moguću deprivaciju „objekta uživanja“ reaguju izrazito negativnim emocijama.

Tabela 2. Karakteristike Internet upotrebe u okviru kliničke grupe

\begin{tabular}{cccccccccc}
\hline pristup & $\%$ & staž & $\%$ & intenzitet & $\%$ & $\begin{array}{c}\text { učesta- } \\
\text { lost }\end{array}$ & $\%$ & $\begin{array}{c}\text { depri- } \\
\text { vacija }\end{array}$ & $\%$ \\
\hline od kuće & 88.0 & $2-3$ god & 16.0 & $7-10 \mathrm{~h}$ & 0.0 & retko & 2.0 & veoma neg. 66.0 \\
sa posla & 8.0 & $3-5$ god & 28.0 & $10-15 \mathrm{~h}$ & 20.0 & ponekad & 8.0 & $\begin{array}{c}\text { umereno } \\
\text { neg }\end{array}$ & 30.0 \\
škola & 4.0 & $\begin{array}{c}5-7 \text { god } \\
\text { preko } 7\end{array}$ & 26.0 & $15-20 \mathrm{~h}$ & 40.0 & često & 90.0 & neutralno & 4.0 \\
& & 30.0 & preko $20 \mathrm{~h}$ & 40.0 & & & & \\
\hline
\end{tabular}

Detaljnija objašnjenja, statističke analize, poređenja i ograničenja za sve do sada iznete rezultate mogu se naći u pomenutom članku (Hinić, 2008).

\section{Klinička slika}

Kao jedan od osnovnih zadataka pri pojavi svakog novog oblika poremećaja ponašanja svakako se nameće definisanje tipične kliničke slike tog poremećaja. Iako postoje brojni podaci (Young, 1998) o najčešćim simptomima na koje se žale zavisnici od Interneta, na našim prostorima takvih podataka nema. Iz tog razloga, u svrhu prikupljanja podataka o tipičnim fizičkim i psihološkim simptomima, primenjena je odgovarajuća lista simptoma (Timotijević \& Paunović, 2003) zadata ispitanicima obe grupe u obliku polustrukturiranog intervjua. Nakon početne statističke obrade, iz prikaza su izbačeni simptomi koji imaju nisku prosečnu ocenu i sniženu ajtem-total korelaciju u odnosu na druge kategorije. Takođe, vrednost Kronbahove alfe za celu skalu značajno se povećala $(85)$ kada su iz nje isključeni pomenuti ajtemi/simptomi. Analiza razlika u odnosu na prosečne vrednosti dobijene kod kontrolne grupe izdvojila je sledeće simptome (Tabela 3.), koji značajno odstupaju u kliničkoj grupi. 
Tabela 3. Prosečne vrednosti intenziteta simptoma kod poremećaja upotrebe Interneta

\begin{tabular}{llll}
\hline $\begin{array}{l}\text { bezvoljnost } \\
\text { problemi sa kon- }\end{array}$ & $\begin{array}{c}2.76^{* *} \text { nervoza, uznemirenost } \\
\text { centracijom }\end{array}$ & $\begin{array}{c}2.46^{*} \text { razdražljivost } \\
\text { njoblemi sa spava- }\end{array}$ & $2.46^{* *}$ \\
$\begin{array}{l}\text { hronična zabrinu- } \\
\text { hrom }\end{array}$ & $\begin{array}{c}\text { manjak energije, } \\
\text { usporenost }\end{array}$ & $2.32^{*}$ \\
tost & $2.32^{*}$ nerazumevanje okoline $2.24^{* *}$ povećana osetlji- & $2.10^{*}$ \\
napadi besa & $1.94^{*}$ gubitak apetita & $1.94^{* *}$ bolovi u leđima & $1.90^{*}$ \\
$\begin{array}{l}\text { bolovi u mišićima } \\
\text { sputanost }\end{array}$ & $1.90^{*}$ glavobolje & $1.80^{*}$ apatija & $1.76^{*}$ \\
\hline
\end{tabular}

** značajnost razlika na nivou $.01{ }^{*}$ značajnost razlika na .05

Možda najzanimljiviji nalazi koji govore o kliničkoj ozbiljnosti poremećaja upotrebe Interneta jesu razlika između indeksa težine poremećaja (GSI - ukupan skor ispitanika podeljen sa 90) kliničke i kontrolne grupe $(\mathrm{t}(98)=-4,617$, $\mathrm{p}<, 001)$, i zastupljenost, odnosno intenzitet fizičkih simptoma u kliničkoj slici ispitanika koji se žale na poremećaj upotrebe Interneta. To se najbolje vidi kod osoba koje imaju teži oblik zavisnosti (viši skor na skali Internet zavisnosti). Ako iz statističke analize izuzmemo ispitanike koji na toj skali imaju skor manji od 65, prosečne vrednosti za fizičke simptome sa SCL liste znatno se povećavaju. Glavobolja sa 1,80 na 2,62 , gubitak apetita sa 1,94 na 2,32 , bolovi u leđima sa 1,90 na 2,76 i manjak energije sa 2,32 na čak 2,98 , su samo neki od tih primera.

Pošto se sama skala sastoji iz deset subskala, izračunati su prosečni skorovi na svakoj od ovih subskala u okviru kliničke grupe i dobijeni rezultati govore da simptomi sa najvećim intenzitetom spadaju u grupe simptoma: hostilnost $(\mathrm{AS}=2,2)$, poremećaj apetita i spavanja $(\mathrm{AS}=2,00)$, depresivnost $(\mathrm{AS}=1,9)$ i socijalnu ranjivost i osetljivost $(\mathrm{AS}=1,79)$.

Kako bi ipak dali širi smisao navedenim nalazima primenjena je faktorska analiza, i metodom glavnih komponenti (Varimaks rotacija, Kajzer normalizacija) analizirana je matrica korelacija između procenjivanih subskala. Primenom Kajzerovog kriterijuma, izdvojeno je četiri faktora koji zajedno objašnjavaju 73\% ukupne varijanse (Tabela 4.). U tabeli su označena zasićenja > 0,6 . 
Tabela 4. Faktorska opterećenja po kategorijama simptoma

\begin{tabular}{lcccc}
\hline & faktor 1 & faktor 2 & faktor 3 & faktor 4 \\
\hline somatizacija & .42 & .66 & -.14 & .10 \\
opses-kompuls & .93 & -.04 & -.07 & -.08 \\
soc.ranjivost & .50 & .51 & .57 & .25 \\
depresivnost & .57 & .68 & .12 & .03 \\
anksioznost & .05 & .43 & .83 & .01 \\
hostilnost & .32 & .11 & -.79 & .92 \\
fobije & .36 & .03 & .68 & .13 \\
paranoidnost & -.09 & .03 & .43 & -.01 \\
psihotičnost & -.03 & .43 & .32 & -.37 \\
apetit/san & .65 & .43 & .09 & -.20 \\
\hline
\end{tabular}

I faktor koji objašnjava 35\% ukupne varijanse, prema meri u kojoj ga zasićuju, čine subskale koje se odnose na dimenziju opsesivno-kompulsivnih simptoma, odnosno psihosomatske posledice kompulsivnosti, kao što su problemi sa apetitom, spavanjem i snom.

II faktor koji objašnjava 15\% varijanse, pokriva simptome depresije i fizičke korelate depresivnosti izražene kroz somatizaciju.

III faktor koji objašnjava $11 \%$ varijanse, odnosi se na dimenziju povećane emotivne osetljivosti i povredivosti, pre svega anksioznost i strah, ali verovatno i usamljenost i socijalnu ranjivost.

IV faktor koji takođe objašnjava $11 \%$ varijanse, iako sa samo jednim značajnim opterećenjem, što svakako predstavlja ograničenje, odnosi se na hostilnost, tačnije na dimenziju agresivnih reakcija, besa, razdražljivost, verovatno izazvanih prekomernom upotrebom Interneta i osećanjem sputanosti.

\section{Internet zavisnost}

Iako je početni kriterijum pri kontruisanju kliničke grupe bio podatak da je dotična osoba zatražila stručnu psihološku/psihijatrijsku pomoć u vezi sa nekim od simptoma prekomerne upotrebe Interneta, ostalo je pitanje da li ta činjenica može, sama po sebi, da govori o postojanju poremećaja koji smo nazvali Internet zavisnost?

Tokom kliničkog intervjua i ispitanih dijagnostičkih kriterijuma (predloženih od strane Američke asocijacije psihologa), došli smo do nalaza da su skoro svi 
potencijalni članovi kliničke grupe ispunjavali blaži kriterijum (pet kriterijuma) za dijagnozu poremećaja upotrebe Interneta $(r=, 880, p<, 001)$. Samo tri ispitanika nisu obuhvaćena zadatim kriterijumima pa su ovi ispitanici bili isključeni iz konačne kliničke grupe i dalje studije. Od ispitanika iz kontrolne grupe, nijedan ispitanik koji je prošao uvodnu selekciju nije ispunjavao najblaži uslov za dijagnozu Internet zavisnosti. Dva kriterijuma koja su se pokazala kao najmanje diskriminativna (najmanji broj javljanja u obe ispitivane grupe) su „osoba skriva svoje ponašanje i prikriva stepen u kome koristi Internet“, i naročito „Internetu se pristupa kao sredstvu rešavanja ili bežanja od aktuelnih problema".

Ovako konstruisane grupe, radi ozbiljnije i detaljnije kvantitativne analize, ispitane su skalom Internet zavisnosti, konstruisanom po ugledu na nekoliko skala (pre svega IAS i CIAS), koje se koriste u više svetskih centara za tretman ovog oblika zavisnosti. Ako na osnovu naših nalaza tokom kliničkog intervjua pretpostavimo da se u slučaju kliničke grupe stvarno radi o ispitanicima sa poremećajem u upotrebi Interneta, na ovaj način želimo da proverimo i valjanost same skale, odnosno njenu moguću prediktivnu vrednost za primenu u dijagnostikovanju ovog poremećaja u našoj sredini.

Interna konzistencija skale ima vrednost Kronbahove $\alpha=, 91$. Radi provere prediktivne vrednosti skale sprovedena je procedura binarne (sa simptomima/bez simptoma) logistične regresije (Tabela 5.), a rezultati pokazuju da veći skor na skali Adiktivnosti predviđa povećanu verovatnoću za poremećajem ponašanja (odds ratio - 1,557).

Tabela 5. Prediktivna vrednost skale Internet zavisnosti

\begin{tabular}{lcccccc}
\hline & B & S.E. & Wald & df & Sig. & Exp(B) \\
\hline Q Adiktivnosti & .443 & .116 & 14.687 & 1 & .000 & 1.557 \\
Constant & -19.212 & 5.028 & 14.597 & 1 & .000 & .000 \\
\hline
\end{tabular}

U daljem postupku, izvršena je komparacija srednjih vrednosti skorova kontrolne i kliničke grupe na skali Zavisnosti i dobijene su značajne razlike $\mathrm{t}(85)=-15,71, \mathrm{p}<, 001$. Konačno, primenom biserijalne korelacije dobijen je $\mathrm{i}$ koeficijent korelacije $\mathrm{r}_{\mathrm{b}}=0,708, \quad \mathrm{p}<, 001$.

Ako se hipotetički poslužimo američkim standardima rangiranja težine Internet zavisnosti po zadatoj skali, videćemo da je samo mali broj ispitanika iz kontrolne grupe uopšte bio blizu granice od 50 poena koja bi ih po toj standardizaciji klasifikovala u grupu blažeg poremećaja u korišćenju Interneta. 
Iako se devet ispitanika kliničke grupe nalazi ispod tog kriterijuma, većina ovih skorova se kreće samo par bodova ispod zadate granice od 50, pri čemu je najniži skor 39. Sa druge strane, ohrabrujući podatak za našu zajednicu je i da samo dva ispitanika beleže skor koji bi ih po američkoj klasifikaciji svrstao u kategoriju težeg poremećaja zavisnosti, pri čemu je najviši skor 85 .

Takođe je zanimljivo da nije identifikovana značajna razlika između koeficijenata zavisnosti muškaraca i žena, kao ni između adolescenata i mladih, u okviru kliničke grupe. Jedina razlika skorova pronađena je između uzrasne kategorije preko 30 godina i kategorije najmlađih korisnika (koji inače imaju i najvišu prosečnu vrednost od svih uzrasnih grupa), i ta razlika je značajna $(\mathrm{t}(24)=$ $3,034, \mathrm{p}<, 01)$.

\section{Diskusija}

Internet je postao osnovno sredstvo putem koga savremeni čovek može na relativno jednostavan, sve jeftiniji i socijalno bezbedniji način doći do relativno brzog zadovoljstva koje putem mehanizma pozitivnog potkrepljenja dalje učvršćuje to ponašanje. Tome dodatno doprinose i reakcije i karakteristike društvene sredine. Osoba može biti odbačena, ili svesno izolovana zbog nekih svojih karakteristika, oblika ponašanja ili načina na koji shvata okolinu. Na taj način Internet određenim ljudima postaje jedna vrsta utočišta od ugrožavajućih draži i situacija, i izvor stalnog pozitivnog iskustva. Uopšteno gledano, osobe koje prekomerno koriste Internet obično se svrstavaju u dve velike grupe. Prvu grupu čine korisnici koji su zavisni od Interneta zbog problema koje imaju u realnim situacijama. $U$ te probleme najčešće se ubrajaju poteškoće $u$ socijalnim odnosima, zdravstveni problemi, ali i mentalni poremećaji kao što su depresija, anksioznost, i sl. (Hinić et al., 2007; Ha et al., 2007; Mihajlović et al., 2008). Drugu grupu čine korisnici koji nemaju drugih posebnih problema osim kompulsivne, prekomerne upotrebe Internet sadržaja i aplikacija koje kod njih izazivaju pozitivno potkrepljenje (druženje, kupovina, lična interesovanja...).

Bez obzira na uzrok same pojave, ovim ispitivanjem je utvrđeno da poremećaj postoji i da se može poprilično jasno opisati njegova klinička slika. Najzanimljivije je to što utvrđene dimenzije simptoma Internet zavisnosti odgovaraju teorijski pretpostavljenim simptomima/poremećajima koji prouzrokuju nastanak samog poremećaja. Pretpostavlja se da Internet zavisnost predstavlja mehanizam odbrane od simptoma depresivnosti, kompulsivnosti, anksioznosti, socijalne anksioznosti, odnosno emotivne nestabilnosti (možda čak i neurotičnosti), i da u stvari ovi poremećaji svoje „odraze“ nalaze u posledicama po- 
našanja koje je u jednom trenutku od strane korisnika protumačeno kao moguće olakšanje i rešenje tih prvobitnih problema.

Hamburger i Ben-Arci su u svojim studijama (Hamburger \& Ben-Artzi, 2000; Hamburger \& Ben-Artzi, 2003) predložili model koji pretpostavlja da ljudi koji već imaju problema sa socijalnom anksioznošću, osećanjem usamljenosti i napuštenosti provode više vremena na Internetu upravo da bi smanjili ili se lišili tog osećaja. Od ispitanika koji su se pre studije (McKenna \& Bargh, 2002) žalili na neke od simptoma depresije (melanholija, osećaj očaja i beznađa, gubitak interesovanja, anksioznost i dr.), 21\% je izjavilo da im je Internet pomogao da se osećaju manje depresivno, na osnovu čega autori zaključuju da Internet kod pojedinih ličnosti služi kao sredstvo rešavanja već postojećih psihopatoloških simptoma. Takođe u brojnim studijama (Lyoo et al., 2000; Ybarra, 2006) su kao posebno rizične, izdvojene populacije osoba sa istorijom opsesivno-kompulsivnih poremećaja, poremećaja kontrole impulsa i drugim oblicima zavisnosti.

Zbog karakteristika nacrta istraživanja (transverzalno-korelativno), ne možemo izbeći ni drugi mogući zaključak, a to je da je prekomerna upotreba Interneta direktan uzrok nastanka pomenutih simptoma, pa čak i odgovarajućih poremećaja, pri čemu ti poremećaji nisu postojali pre nastanka Internet zavisnosti. Ipak, prema trenutnoj empirijskoj građi koja postoji u istraživačkim krugovima ovog poremećaja, što je manje verovatan „scenario“ (Hamburger \& Ben-Artzi, 2000; Davis, 2001). Ovo je takođe verovatan razlog zašto studije koje su pokušavale da potvrde vezu između Internet zavisnosti i pojedinačnih psiholoških poremećaja, najčešće u tome nisu uspevale na nivou statističke značajnosti, jer je očigledno da Internet predstavlja pogodno sredstvo za „ublažavanje" većeg broja različitih potreba i različitih psihičkih simptoma i problema koji se međusobno prepliću.

Takođe bitan nalaz je onaj koji govori o ozbiljnosti fizičkih simptoma u kliničkoj slici prekomerne upotrebe Interneta, koji se poklapaju sa tipičnim simptomima bilo kog drugog oblika (bihevioralne) zavisnosti, pri čemu postoji značajna razlika između indeksa težine poremećaja kliničke i kontrolne grupe. Kako ovoj studiji nije bio cilj utvrđivanje smera korelacije koje Internet zavisnost može imati sa specifičnim poremećajima ličnosti, kao ni korelata koje Internet zavisnost može imati u specifičnim strukturama ličnosti, dalje zaključke ne smemo donositi, osim ideje da je nužno u budućnosti dublje ispitati mogući smer veze sa pomenutim psihičkim poremećajima, kao i postojanje veza sa određenim tipovima ličnosti, preciznije rečeno, uverenjima i ličnim konstruktima koji dalje određuju personalne tendencije prema nekim od navedenih poremećaja. 
Kada je u pitanju detaljnije, kvantifikovano merenje ovog poremećaja, skala Internet zavisnosti je pokazala visoku korelaciju sa ponašanjem koje smo definisali kao prekomerna upotreba Interneta. Takođe je potvrđena statistički značajna razlika skorova na skali Internet zavisnosti između kliničke i kontrolne grupe, kao i prediktivna vrednost skale Internet zavisnosti za postojanje simptoma Internet zavisnosti. Naš cilj, trenutno, nije bio standardizacija ove skale, tako da je dalja detaljnija analiza i adaptacija pojedinačnih ajtema, kao i standardizacija celokupne skale za našu sredinu nužna.

\section{Zaključak}

Evidentno je da prekomerna upotreba Interneta može postepeno dovesti do zanemarivanja profesionalnih i socijalnih relacija i obaveza, uz očiglednu pojavu i telesnih tegoba. Svi ispitanici iz naše kliničke grupe su se požalili na neke od tih simptoma, zbog čega su se prevashodno i obratili za stručnu pomoć. Rezultati nesumnjivo govore da je ovde reč o određenoj vrsti psihičke disfunkcije, iako postoje polemike o njenom nazivu.

Kvalitativna analiza fizičkih simptoma i odgovora korisnika koji u prekomernom obimu koriste Internet, sugeriše fenomenološku sličnost sa simptomima drugih oblika adiktivnih poremećaja. Zadovoljstvo i olakšanje, pa čak i euforija u trenutku samog pristupa, ili nervoza i razdražljivost prilikom otežanog pristupa poklapaju se sa „dvostrukim licem“ bilo kog do sada izdvojenog oblika zavisnosti. Iz tog razloga, skloni smo da po pitanju dilema oko klasifikacije ovog poremećaja ponašanja, sugerišemo njegovo svrstavanje u dijagnostičku kategoriju bihevioralnih adikcija, pri čemu bi korišćenje termina Internet zavisnost imalo potpunu legitimnost. Samim tim, javlja se i potreba za skorašnjom standardizacijom neke od trenutno postojećih skala Internet zavisnosti, kako bi se ostvarile sve preventivne mere za njeno otkrivanje i suzbijanje. Skala korišćena u ovoj studiji pokazala je zadovoljavajuću prediktivnost, pa može predstavljati osnovu za konstruisanje sličnog instrumenta primenjivog na našoj populaciji. Iako je jedan od zadataka pri konstrukciji tog novog instrumenta i utvrđivanje normi i razreda u stepenu zavisnosti, ako se primene postojeći američki standardi za sličnu skalu Internet zavisnosti, ohrabrujući podatak za našu zajednicu je da se najveći broj ispitanika iz kliničke grupe kreće u okviru granica blažeg poremećaja upotrebe Interneta, koji karakterišu povremeni ili ređe učestali problemi/simptomi nastali usled prekomerne upotrebe istog. 


\section{Reference}

Bai, Y.M., Lin, C.C. \& Chen, J.Y. (2001). Internet addiction disorder among clients of a virtual clinic. Psychiatric Services, 25, 1397.

Beard, K. \& Wolf, E. (2001). Modification in the Proposed Diagnostic Criteria for Internet Addiction. Cyberpsychology \& Behavior, 4, 377-383.

Bugarski, V. (2003). Zavisnost od interneta - na putu ka novoj dijagnostičkoj kategoriji. Aktuelnosti iz neurologije, psihijatrije i graničnih područja, 11 (2), 50-56.

Cheng, S.H., Weng, L.J., Su, Y.J., Wu, H.M. \& Yang, P.F. (2003). Development of a Chinese Internet Addiction Scale and it's psychometric study. Chinese Journal of Psychology, 45, 279-294.

Chou, C. (2001). Internet heavy use and addiction among Taiwanese college students: an online interview study. Cyberpsychology and Behavior, 4 (5), $573-585$.

Cole, J. I. (2003). The UCLA Internet Report. Surveying the Digital Future, year three. California, UCLA.

Davis, R.A. (2001). A cognitive-behavioral model of pathological Internet use. Computers in Human Behavior, 17, 187-195.

Derogatis, L.R. (1977). SCL-90-R, Administration, Scoring and Procedures Manual 1. Baltimore: Clinical Psychometric Research.

Derogatis, L.R. (1981). Description and bibliography for the SCL-90-R. Baltimore: Johns Hopkins University.

Golčevski, N. i Milanović, G. (2003). Globalni gradani - Empirijska studija korisnika Interneta u Srbiji 2003. Beograd, CePIT.

Golčevski, N., Milanović, G., Petrović, M. i Sitarski, M. (2004). Perspektive umrežavanja - Internet u 8 gradova Jugoistočne Evrope. Beograd, CePIT.

Ha, J. H.. (2007). Depression and Internet Addiction in Adolescents. Psychopathology, 40 (6), 424-430.

Hamburger, Y.A. \& Ben-Artzi, E. (2000). The relationship between extraversion and neuroticism and the different uses of the Internet. Computers in Human Behavior, 16, 441-449.

Hamburger, Y.A. \& Ben-Artzi, E. (2003). Loneliness and internet use. Computers in Human Behavior, 19, 71-80. 
Hinić, D. (2007). Upotreba Interneta i društveni život njegovih korisnika. Beograd, Empirijska istraživanja u psihologiji XIII. Retrieved February 10, 2007 from: http://www.empirijskaistrazivanja.org/html/rezime07/socijalna/r16.htm

Hinić, D., Mihajlović, G., Djukić-Dejanović, S. i Jovanović, M. (2007). Increased Internet use and Social Isolation. Engrami, 29 (3-4), 47-62.

Hinić, D., Mihajlović, G., Špirić, Ž., Đukić-Dejanović, S. \& Jovanović, M. (2008). Excessive Internet use - Addiction Disorder or not? Vojnosanitetski pregled, 65 (10), 763-767.

Hinić, D. (2008). User profiles of Internet addicts in Serbia. Psihologija, 41 (4), 435-453.

Holden, C. (2001). Behavioral addictions: do they exist? Science, 294, 980-982.

Lyoo, I.K., Ha, J.H., Yang, E.J., Kim, Y.M., Chang, C.G. \& Woo, J.I. (2000). Psychopathology of Internet addiction: perspective of impulsivity and obsessive compulsivity. Korean Journal of Psychopathology, 9, 16-26.

Madden, M. \& Rainie, L. (2003). America's Online Pursuits: The changing picture of who's online and what they do. USA, Pew Internet and American Life Project.

McKenna, K.Y.A. \& Bargh, J.A. (2002) Can You See the Real Me? Activation and Expression of the 'True Self' on the Internet. Journal of Social Issues, (58-1), 33-48.

Mihajlović, G., Hinić, D., Damjanović, A., Gajić, T. \& Đukić-Dejanović, S. (2008). Excessive Internet Use and Depressive Disorders. Psychiatria Danubina, 20 (1), 5-14.

Milanović, G., Bakić, I. i Golčevski, N. (2002). Internet pregled: Beograd 2002. Beograd, CePIT.

Mitchell, P. (2000). Internet addiction: genuine diagnosis or not? Lancet, 355, 632.

Nie, N. \& Erbring, L. (2000). Internet and Society: A Preliminary Report, Stanford, CA: SIQSS.

Thomas, H. A., Hester, R. K. \& Marlatt, G. A. (1999). Sex, Drugs, Gambling E Chocolate: A Workbook for Overcoming Addictions. San Luis Obispo, CA, Impact Publishers. 
Timotijević, I. \& Paunović, V.R. (2003). Instrumenti kliničke procene u psihijatriji. Beograd: Institut za mentalno zdravlje.

Ybarra, M. (2006). The Role of Adolescent Depressive Symptomatology in Internet Experiences. Baltimore: Johns Hopkins University.

Yellowlees, P.M. \& Marks, S. (2007). Problematic Internet use or Internet addiction? Computers in Human Behavior, 23, 1447-1453.

Yen, J.Y., Ko, C.H., Yen, C.F., Chen, S.H., Chung, W.L. \& Chen, C.C. (2008). Psychiatric symptoms in adolescents with Internet addiction: Comparison with substance use. Psychiatry and Clinical Neurosciences, 62, 9-16.

Young, K. (1998). Internet addiction: The emergence of a new clinical disorder. CyberPsychology and Behavior, 1, 237-242.

Whang, L.S.M., Lee, S. \& Chang, G. (2003). Internet over-users' psychological profiles: a behavior sampling analysis on internet addiction. CyberPsychology \& Behavior, 6 (2), 143-150. 


\section{ABSTRACT}

\section{SYMPTOMS AND DIAGNOSTIC CLASSIFICATION OF THE INTERNET ADDICTION DISORDER IN SERBIA}

\section{Darko Hinić}

The aim of this study was to determine typical clinical characteristics of Internet use disorder in Serbia, as well as to test the validity of the Internet addiction scale in predicting the disorder. The secondary aim was the evaluation of the proposal to categorize this disorder into the category of behavior addictions.

The study was designed as a comparative analysis of Internet users with and without excessive and dysfunctional Internet use symptoms. The study recruited 100 subjects in total, 50 in both the clinical and control group. The clinical group included the Internet users who asked for professional help due to the symptoms of excessive Internet use, and also met the criteria of Internet behavior disorder. The typical symptoms were recorded with the adapted scale of psycho-physical symptoms.

The Internet use disorder is comprised of four, to a certain extent separated, symptom dimensions: obsessive-compulsiveness, depression, hostility, anxiety and emotional sensitivity, were established symptom dimensions of Internet addiction correspond with theoretically hypothesized symptoms/disorders which bring about the disorder itself. The important finding of the study is that the Internet addiction scale has proved to be highly discriminating (odds ratio $-1,557)$ in predicting Internet use disorders. The Internet addiction scale is in high correlation $\left(\mathrm{r}_{\mathrm{b}}=0,708, \mathrm{p}<, 001\right)$ with the mentioned behaviour disorder which provides empirical bases to the idea that the above mentioned form of behaviour may be classified under behavior addictions.

Key words: addictions, diagnostic criteria, Internet addiction disorder 